\title{
Effects of Farm Bill Commodity Subsidies on US Corn Production, Farm Income, and Market Price
}

\author{
By Dana Hecht
}

This paper outlines the effects of farm bill subsidies on corn farmers' planting decisions, overall production, corn farmer income and market price of corn. The author utilizes a series of real and hypothetical market prices to demonstrate the particular combinations of subsidies that are available for corn farmers under varying market conditions. Research suggests that certain subsidies are theoretically capable of increasing production above normal levels when prices of corn fall below a certain threshold. However, in practice, prices of corn have not fallen below this threshold for extended periods of time, and thus this scenario has rarely presented itself historically. The author concludes that because they provide income support for corn farmers and create a safety net for corn prices, these subsidies represent an incentive in itself to grow corn over other non-subsidized produce. Thus, it is possible that corn subsidies have led to the growth of the industry over time by influencing the choices that farmers have made throughout history upon entering the market, rather than by influencing day-to-day planting decisions throughout the crop season.

\section{Introduction}

Adoption of a 2012 Farm Bill is currently overdue for its scheduled renewal, which takes place every four to five years, and a one-year extension of the 2008 bill is in place until Congress passes the new, revised legislation. Due to this pending renewal, and in light of the current budget crisis and the focus on deficit reduction, it is important to understand the cost of farm bill subsidies and their effect on commodity crop production and market prices. Though corn production is largely driven by demand for a wide variety of products (including ethanol and animal feed as well as corn for human consumption), corn subsidies in particular have received some negative public attention due to the notion that they lead to the overproduction of corn and products like high-fructose corn syrup (Barrionuevo 2005; Roberts 2008, 116-124; Pollan 2008, 161). To address this issue, this paper discusses how corn subsidies affect corn production in the United States. This paper first explains the nuances of the different subsidies available to corn farmers, focusing on the distinction between coupled and decoupled payments. It then uses a set of case studies to demonstrate the effect of enrollment in multiple subsidy programs on corn farmers' planting decisions, overall production, the market price of corn, and farmer income under both real and hypothetical market conditions. The paper concludes by suggesting areas of further research needed to determine the relative incentives for producing corn over other non-commodity produce.

\section{Background: Commodity Subsidies for Corn}

The Commodity title of the 2008 U.S. Farm Bill establishes five major types of payments for farmers that pro- 
duce commodity crops (which include corn, wheat, soy, rice, cotton, sugar, and peanuts, among others). Eligible farmers can receive one or multiple types of the following loans: marketing assistance loans, loan deficiency payments, direct payments, counter-cyclical payments, and average crop revenue election payments (USDA ERS 2012a). These payments are implemented at the federal level through the United States Department of Agriculture (USDA) and are "opt-in" payments farmers must apply to receive them. Table 1 summarizes the requirements, payment, scheduling, and repayment rates, as well as payment limits and restrictions, for each of these five types of subsidies.

The economic effects of these subsidies on planting decisions depend on whether the subsidy is coupled or decoupled. Coupled payments, which are positively correlated with current production, can influence planting decisions, distort production, and impact market prices. Decoupled payments, which are tied to established, historical base acres and yields and thus do not impact current production decisions, are considered to be less distorting to commodity markets (USDA ERS 2012b). Marketing assistance loans and loan deficiency payments are coupled with current production, while direct pay-

Table 1: Commodity Subsidies and Loan Conditions for Corn

\begin{tabular}{|c|c|c|c|c|c|}
\hline & Type of loan & $\begin{array}{l}\text { Requirements \& } \\
\text { Conditions }\end{array}$ & $\begin{array}{l}\text { Payment Rate, Calculation \& } \\
\text { Schedule }\end{array}$ & Repayment & $\begin{array}{l}\text { Limits \& } \\
\text { Restrictions }\end{array}$ \\
\hline \multirow{3}{*}{$\begin{array}{l}\text { C } \\
0 \\
\text { U } \\
\text { P } \\
\text { L } \\
\text { E } \\
\text { D }\end{array}$} & \multirow{3}{*}{$\begin{array}{l}\text { Marketing } \\
\text { Assistance Loans } \\
\text { (MAL) } \\
\& \\
\text { Loan Deficiency } \\
\text { Payments (LDP) }\end{array}$} & \multirow[t]{2}{*}{$\begin{array}{l}\text { Paid to farmers of } \\
\text { covered commodities, } \\
\text { including corn. }\end{array}$} & \multirow{2}{*}{$\begin{array}{l}\text { MAL Rate }=\$ 1.95 / \text { bushel } \\
\text { Loans are disbursed at the end of the } \\
\text { harvest, and expire } 9 \text { months after } \\
\text { approval. }\end{array}$} & $\begin{array}{l}\text { If } \mathrm{p}<\text { (MAL + interest), } \\
\text { farmers can forfeit } \\
\text { collateral }\end{array}$ & \multirow[b]{3}{*}{$\begin{array}{l}\text { y } 30 \% \text { for } \\
\text { enrolled in }\end{array}$} \\
\hline & & & & $\begin{array}{l}\text { If } \mathrm{p}<\text { (MAL + interest), } \\
\text { farmers can repay loan } \\
\text { at rate }=\mathrm{p} \text {, no interest. }\end{array}$ & \\
\hline & & $\begin{array}{l}\text { Paid when prices for } \\
\text { corn are below MAL } \\
\text { payment rates } \\
\text { (i.e. when } p<\$ 1.95 \text { ) }\end{array}$ & $\begin{array}{l}\text { LDP }=(\text { MAL-p) } \times Q \\
\text { MAL=\$1.95 } \\
\text { Payments can be made during } \\
\text { harvesting through May } 31 \text { annually. }\end{array}$ & N/A & \\
\hline \multirow{3}{*}{$\begin{array}{l}D \\
E \\
C \\
O \\
U \\
P \\
\text { L } \\
\text { E } \\
D\end{array}$} & $\begin{array}{l}\text { Direct Payments } \\
\text { (DP) }\end{array}$ & $\begin{array}{l}\text { Eligible acreage: } 10+ \\
\text { acres }\end{array}$ & $\begin{array}{l}\text { DP Rate }=\$ 0.28 / \text { bushel } \\
\text { DP= (MAL) x [..85)(payment acres)] x } \\
\text { (yield/acre) x (DP rate) } \\
\text { MAL= } \$ 1.95 \\
\text { Payments made starting Oct. } 1 \text { of } \\
\text { harvest year. Advance payments (up } \\
\text { to } 22 \% \text { ) can be made starting Dec. } 1 \\
\text { preceding harvest year. }\end{array}$ & $\mathrm{N} / \mathrm{A}$ & $\begin{array}{l}\text { Max total: } \\
\$ 40,000 / \text { year } \\
\text { If AGl > } \$ 750 K \text {, cannot } \\
\text { receive DP's } \\
\text { Reduced by } 20 \% \text { for } \\
\text { producers enrolled in } \\
\text { ACRE }\end{array}$ \\
\hline & $\begin{array}{l}\text { Counter-cyclical } \\
\text { Payments (CCP) }\end{array}$ & $\begin{array}{l}\text { Eligible acreage: } 10+ \\
\text { acres } \\
\text { Paid when target price } \\
\text { (TP) > effective price } \\
\text { (EP) } \\
\text { Target price= } \$ 2.63 \\
\text { EP = DP+MAL or } \\
\text { EP=DP + p } \\
\text { Whichever amount is higher }\end{array}$ & $\begin{array}{l}\text { CCP Rate } \$ 0.40 / \text { bushel } \\
\text { (maximum) } \\
\text { CCP=(MAL) } \times[[.85) \text { (payment acres)] } \\
\times \text { (yield/acre) } \times(C C P \text { rate }) \\
\text { CCP=TP-EP } \\
\text { Partial payments made starting after } \\
\text { first } 180 \text { days of marketing year } \\
\text { (Sept. 1- Aug 31). Final payments } \\
\text { made atter end of marketing year. }\end{array}$ & $\mathrm{N} / \mathrm{A}$ & $\begin{array}{l}\text { Max total: } \\
\$ 65,000 / \text { year }\end{array}$ \\
\hline & $\begin{array}{l}\text { Average Crop } \\
\text { Revenue Election } \\
\text { Payments (ACRE) }\end{array}$ & $\begin{array}{l}\begin{array}{l}\text { Eligible acreage: } 10+ \\
\text { acres }\end{array} \\
\text { State revenue < } \\
\text { Program guarantee, } \\
\text { and... } \\
\text { Farm revenue }< \\
\text { Benchmark farm } \\
\text { revenue }\end{array}$ & $\begin{array}{l}\text { ACRE }=\text { (Program guarantee- State } \\
\text { Revenue) } x[[.85) \text { (farm acres)] x } \\
\text { [relative productivity ratio] } \\
\text { (Program guarante- State Revenue) is } \\
\text { substituted with [[.25)(Program guarantee)] } \\
\text { when this amount is lower. } \\
\text { Payments made starting Oct. } 1 \text { or, } \\
\text { beforehand, after end of marketing } \\
\text { year [Aug. 31]. }\end{array}$ & $\mathrm{N} / \mathrm{A}$ & $\begin{array}{l}\text { Max totali } \\
\$ 65,000 / \text { year }\end{array}$ \\
\hline
\end{tabular}

Source: Author's own compilation from Congressional Research Service (CRS), USDA Economic Research Service (ERS) data in ERS 2012a-g and USDA Farm Service Agency (USDA FSA) data in 2011a-b, 2012.

$\mathrm{p}=$ price; $\mathrm{AGI}=$ adjusted gross income 
ments, counter-cyclical payments, and the average crop revenue election program are tied to historical base acres and yield, and are thus decoupled.

\section{Coupled Payments}

Coupled payments are dependent on market price and thus have the potential to distort production levels when prices fall. The following paragraphs outline the payment determinations for the two types of coupled payments: marketing assistance loans and loan deficiency payments.

Marketing assistance loans for corn can be paid to farmers at a rate of $\$ 1.95$ per bushel at the end of the harvest (in October and November), and must be repaid in full, plus interest, to the Commodity Credit Corporation upon loan maturity unless the market price per bushel is less than the loan amount per bushel upon maturity (USDA FSA 2011a; Monke 2006). In order to secure marketing assistance loans, farmers agree to store their crop during harvest when prices are low; this stored crop is then used as collateral for the loan. This aspect of the loan agreement makes the loan a mechanism for regulating market flows throughout the year (USDA FSA 2011a). Before loan maturity, which occurs nine months after the approval of the loan, if prices are below $\$ 1.95$ per bushel then farmers can choose to forgo the stored corn they used as loan collateral or they can repay the loan at a rate equal to the depressed market price, and all accrued interest is waived (USDA FSA2012; USDA ERS 2012c).

Instead of receiving a marketing assistance loan, when prices of corn fall below $\$ 1.95$ per bushel, corn farmers can opt to receive a loan deficiency payment. These are onetime payments paid per bushel produced that farmers do not repay. These loan deficiency payments are equal to the difference between the marketing assistance loan rate and the market price. Corn farmers can receive these payments during harvesting and through May 31 of every year (USDA FSA 2011b). Loan deficiency payments are equal to the por- tion of the subsidy the corn farmers would retain when a marketing assistance loan is obtained and repaid later at the lower rate (i.e. market price). Instead of receiving the loan and paying it back at a lower rate, when corn prices fall below $\$ 1.95$ per bushel the farmers simply receive the difference between these two amounts as a retroactive payment (USDA ERS 2012g).

These marketing assistance loans and loan deficiency payments establish an effective price floor of $\$ 1.95$ per bushel for farmers. When actual market prices are lower than this rate, corn farmers produce a higher amount of corn than they would if these benefits were not in place (Price and Westcott 2001).

\section{Decoupled Payments}

Unlike coupled payments, decoupled payments are not dependent on market price, and thus do not have the same potential to distort production levels when prices fall. The following paragraphs outline the payment determinations for each of the three types of decoupled payments: direct payments, counter-cyclical payments, and average crop revenue election payments.

Direct payment rates are $\$ 0.28$ per bushel of corn produced, and farms with 10 or more acres can receive these subsidies (Monke 2006, USDA ERS 2008). The total amount farmers receive in direct payments equals the product of marketing assistance loans ( $\$ 1.95 /$ bushel), 85 percent of farm acreage, farm yield (in bushels per acre), and the direct payment rate for corn ( $\$ 0.28 /$ bushel). Corn farmers can receive a maximum total of $\$ 40,000$ in direct payments annually. All corn farmers whose adjusted gross income falls below $\$ 750,000$ per year are eligible to receive this type of subsidy (USDA ERS 2012d).

Counter-cyclical payments are made to farms of 10 or more acres when established target prices for corn $(\$ 2.63$ per bushel) are higher than effective prices. The effective price is defined as the sum of the direct payment rate per bushel plus either the marketing assistance loan rate 
(\$1.95 per bushel) or the market price, whichever amount is higher (USDA ERS 2008, 2012e). Counter-cyclical payments can be provided at a maximum rate of $\$ 0.40 /$ bushel for a maximum total of $\$ 65,000$ annually (USDA ERS 2012e). Total counter-cyclical payments received by corn farmers equal the product of marketing assistance loans ( $\$ 1.95 /$ bushel), 85 percent of farm acreage, farm yield (in bushels per acre), and the counter-cyclical payment rate for corn (the difference between target and effective prices) (USDA ERS 2012e).

Average crop revenue election payments, first introduced in the 2008 Farm Bill, are an alternative to countercyclical payments, and the maximum amount that corn farmers can receive of this type of payment is also $\$ 65,000$ (USDA ERS 2012f). This type of payment provides guaranteed revenue to participating corn farmers based on market prices and average yields; however, receiving these payments reduces the amount of direct payments corn farmers can receive by 20 percent and loan deficiency payments by 30 percent (USDA ERS 2012f). Because average crop revenue election is a newer component of the farm bill, and because it can only be used in place of counter-cyclical payments, this paper will not elaborate on the specific economic implications associated with this type of payment in the following corn farmer case study.

\section{A Corn Farmer Case Study}

This case study discusses the sets of payments available to corn farmers under market scenarios depicted in Figure 1. The first scenario demonstrates average revenues secured by corn farmers under current market conditions, which are above the target price of $\$ 2.63$ per bushel. The remaining scenarios are hypothetical and demonstrate the payments available to farmers and their effect on revenue and planting decisions when prices fall below $\$ 1.95$ per bushel, between $\$ 1.95$ and $\$ 2.35$ per bushel, and between $\$ 2.35$ and $\$ 2.63$ per bushel, respectively. For the purposes of observing the impact of counter-cyclical payments on farmer income, this case study assumes that the farmer does not enroll in the average crop revenue election program.

The scenarios also utilize a hypothetical farmer that owns and uses a calculated average corn farm size (in acres) and produces average corn yields on that farm. Table 2 displays USDA data on total acreage of corn farms, number of corn farms, and average national yield of corn, and contains derived average corn farm size and yield per farm.

\section{Revenues Under Coupled Programs at Current Market Price}

USDA data from 2010 and 2011 crop years indicate that the market price of corn was $\$ 5.18$ per bushel on a national level (USDA ERS 2013b). Using data from

Figure 1: Relationship of Commodity Payments to Market Prices

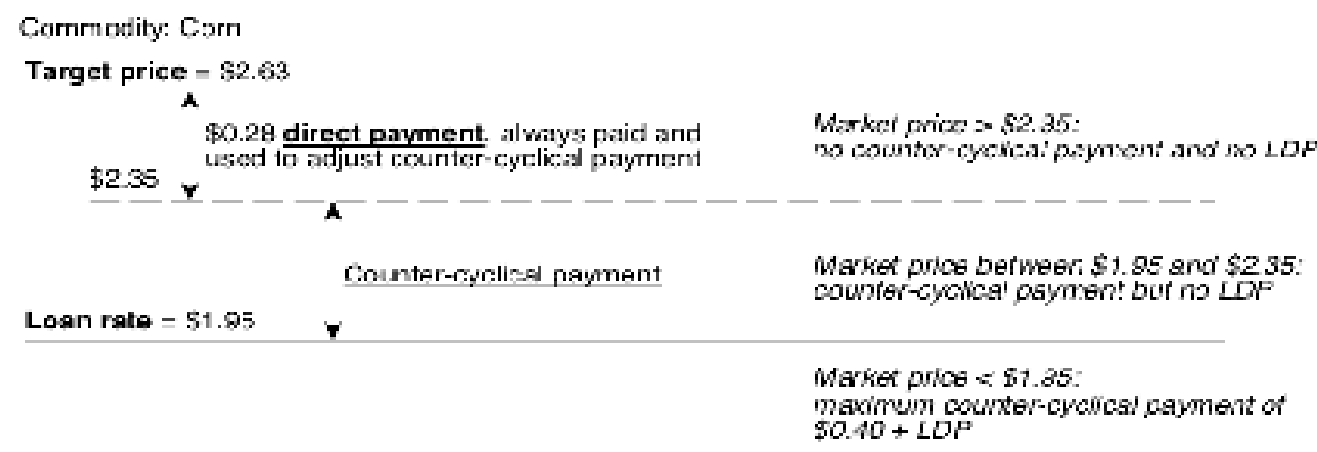

Source: Monke 2006. 
- Effects of Farm Bill Commodity Subsidies

Table 2: Corn Farm Data: Total and Average Farm Size and Yield

\begin{tabular}{|c|c|c|c|c|}
\hline Total acreage & $\begin{array}{c}\text { Number of } \\
\text { corn farms }\end{array}$ & $\begin{array}{c}\text { Average corn } \\
\text { farm size }\end{array}$ & $\begin{array}{c}\text { Average } \\
\text { yield/acre }\end{array}$ & $\begin{array}{c}\text { Average } \\
\text { yield/farm }\end{array}$ \\
\hline 88.19 million & $\begin{array}{c}347,760 \\
\text { farms }\end{array}$ & 253.59 acres & $\begin{array}{c}152.80 \\
\text { bushels }\end{array}$ & $\begin{array}{c}38,749.23 \\
\text { bushels }\end{array}$ \\
\hline
\end{tabular}

Sources: Author's own compilation from USDA Yearbook Tables (ERS 2013a, 2013b)

and Census of Agriculture 2007.

Average corn farm size derived from total acreage and number of farms.

Average yield per farm derived from average corn farm size and average yield per acre.

Table 2, this corn farmer can obtain marketing loan rates at $\$ 1.95$ per bushel and direct payments of $\$ 0.28$ per bushel. The farmer is not able to receive loan deficiency payments under the current market price of corn, as it is higher than the marketing assistance loan rate. Similarly, the farmer cannot receive counter-cyclical payments because the effective price of corn (effective price $=$ direct payment $+p=\$ 5.46$ ) is above the established target price of $\$ 2.63$ (see Figure 1). However, assuming the farmer is able to sell all of his bushels of corn at market price ( $\$ 5.18$ per bushel), he can receive a marketing assistance loan and direct payments equaling $\$ 294,029.83$ total (see Appendix). This calculation assumes that the historical base acres and yield for direct payments recorded when the farmer applied to receive direct payments are also equal to the current, average farm size and yield in Table 2.

Under these market conditions, the farmer would not be able to forfeit stored corn as collateral, and because the market price per bushel is greater than the marketing assistance loan rate plus accrued interest (Commodity Credit Corporation interest rates $=3.00$ percent for a seven-year loan, June 2010), the farmer would be required to repay the loan at the current marketing assistance loan rate (\$1.95 per bushel) plus interest accrued, increased by 1 percent nine months after the loan is approved (USDA ERS 2012g, USDA FSA 2010). The farmer's revenue in this scenario would be $\$ 282,544.56$ (see Appendix). Because market prices are higher than marketing assistance loan rates in this scenario, and the farmer is required to pay back the marketing assistance loan and accrued interest, the marketing assistance loan itself provides no incentive for the corn farmer to increase production - it only provides shortterm income support.

\section{Revenues Under Coupled Programs at Hypothetical Market Prices}

When Market Price Falls Below the Marketing Loan Rate of \$1.95 per Bushel

In the event that market prices of corn fall below the marketing assistance loan rate, the farmer can gain revenue from the difference between the loan rate and the loan repayment rate (because the loan repayment rate is equal to the depressed market price). In fact, if the market price falls below the marketing assistance loan rate plus interest, the farmer needs only to repay the loan at market price per bushel (interest fees are waived) (USDA ERS 2012g). The relationship between marketing assistance loans, counter-cyclical payments, and direct payments is shown in Figure 1 (Monke 2006).

If the market price per bushel of corn falls below $\$ 1.95$ per bushel (e.g. to $\$ 1.50$ per bushel), the farmer would receive marketing assistance loans and direct payments as well as counter-cyclical payments at the maximum rate $(\$ 0.40$ per bushel). Using the same data in Tables 1 and 2, and assuming the farmer was able to sell all corn produced at a market price of $\$ 1.50$, these provisions would amount to a total of $\$ 3.45$ per bushel plus the maximum direct payment of $\$ 40,000$ and 
the maximum counter-cyclical payment of $\$ 65,000$, for a total of $\$ 238,684.84$ in income.

In this specific case, the farmer could choose to either forgo the corn stored as collateral (representing a loss in income of $\$ 1.50 \times 38,749.23$ bushels= $\$ 58,123.85$ ), or to repay the loan at the lower market price per bushel produced (also $\$ 58,123.85$ ). Whether the farmer forfeits his stored collateral or repays the loan at the lower market price, the resulting revenue would be $\$ 180,560.99$ (see Appendix). This is the result regardless of which option the farmer chooses, because the value of the lost corn collateral is equal to the value of the total amount of corn produced. The gain the farmer realizes in this instance is the difference between the marketing assistance loan received and the repayment rate (the depressed market price): $\$ 0.45$ per bushel, or $\$ 17,437.15$ (see Appendix). Instead of receiving the marketing assistance loan and paying back the loan at the market price, the farmer could have chosen to receive a loan deficiency payment equal to the difference between the marketing assistance loan and market price, multiplied by the number of bushels produced. This results in the same overall gain of $\$ 17,437.15$.

Because marketing assistance loans are coupled with production, when market prices fall below $\$ 1.95$ per bushel and the corn farmer realizes this marketing loan gain, it is favorable for the farmer to produce the amount demanded by the market at that lower market price in order to maximize income (a greater amount than would be favorable to produce without this subsidy). These coupled payments represent a paradoxical situation: if all corn farmers choose to increase production when market prices are low in order to maximize total income with subsidies, the resulting oversupply could further depress market prices and could lead to increased dependence on marketing assistance loans and loan deficiency payments for income.

When Market Price Falls Between \$1.95 and \$2.35 per Bushel
If the market price per bushel of corn falls between $\$ 2.35$ and the marketing assistance loan rate of $\$ 1.95$ per bushel, the corn farmer would be eligible to receive direct payments and counter-cyclical payments in order to achieve an established target price of $\$ 2.63$ per bushel. However, since decoupled payments are dependent on a pre-established historical base acreage and yield for the farm and not current per bushel production, these subsidies would not incentivize farmers to increase production when market prices fall between $\$ 1.95$ and $\$ 2.35$. Just as was the case in the current market price scenario for corn (\$5.18 per bushel), all marketing assistance loans that are received by farmers would be repaid plus interest. This scenario also creates no incentive for corn farmers to increase production.

When Market Price Falls Below the Target Price and Above \$2.35 per Bushel

Finally, at a market price between the rate of $\$ 2.35$ per bushel and the target price of \$2.63 per bushel, the only decoupled payment that farmers would receive are direct payments. Again, since direct payments are decoupled and do not depend on current rates of production, the corn farmer would not be incentivized to increase production. Any marketing assistance loans received would also be required to be repaid in full plus interest, so receiving these loans would not lead to marketing gains as they do when the market price falls below the loan rate of $\$ 1.95$ per bushel.

\section{Implications of Payments Coupled with Current Production}

In the case where marketing assistance loans given to corn farmers are due to a decrease in market price below \$1.95 per bushel, corn farmers receive a marketing loan benefit equal to the bracketed area in Figure 2 (Price and Westcott 2001). The benefit farmers receive is often slightly larger than the difference between the loan rate and the depressed market price. This occurrence is due to the fact that, in practice, farmers have chosen to 
Figure 2: Supply and Demand, with Realized Benefits of Marketing Loans

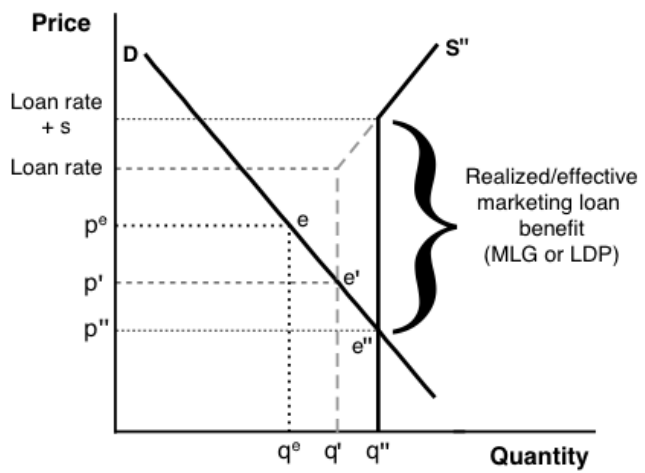

MLG $=$ Marketing Loan Gain.

LDP = Loan Deficiency Payment

Source: Price and Westcott 2001.

(Reprinted with permission.)

obtain the loan benefit (by either repaying the marketing assistance loan, or by receiving the loan deficiency payment) when seasonal prices for corn are at their lowest (Price and Westcott 2001). In Figure 2, this additional increase in the corn farmer's revenue gain is equal to " $\mathrm{s}$ " (in "loan rate $+s$ " on the vertical axis) (Price and Westcott 2001).

These marketing assistance loans establish an effective price floor for corn of \$1.95 per bushel, meaning that farmers still receive this amount in revenue per bushel even when market prices fall below this rate. This price floor introduces a potential market distortion - instead of decreasing production, corn farmers are incentivized to continue producing the same amount of corn as they had before market prices fell below this rate. This lack of responsiveness to market price decreases below $\$ 1.95$ per bushel explains the partial inelasticity in the suply curve shown in Figure 2, and also highlights the fact that when prices fall, a greater amount of corn is produced than is demanded. The excess supply created in this scenario is depicted by the shaded triangle (bounded by the diagonal supply curve under no market distortions, the depressed market price $\mathrm{p}$," and the fixed quantity produced at this price floor q") in the modified graph in Figure 3.

\section{Conclusion \& Recommendations for Further Research}

As demonstrated through the analysis of subsidies available in these alternative corn price scenarios, corn farmers' current planting decisions are only impacted by coupled commodity subsidies when market prices of corn fall below the marketing assistance loan rate of $\$ 1.95$ per bushel. According to USDA data, average prices of corn received by farmers dropped below this price during only four months over the past decade, September through December of 2005 (USDA ERS 2013b). Though these are average prices for corn and do not perfectly reflect the daily, county-specific market prices that determine loan benefits, USDA simulation models suggest that these marketing assistance loans and loan deficiency payments have had relatively little overall effect on planted acreage and price of corn, as shown in Figures 4 and 5 (Price and Westcott 2001).

Based on this data, and assuming market prices for corn remain above the marketing assistance loan rate, we can predict that these loans would have minimal impact on the planting decisions of current farmers and on the market price of corn. A discontinuation of subsidies that are coupled with production, even in periods when the market price of corn

Figure 3: Supply and Demand, with Realized Benefits of Marketing Loans

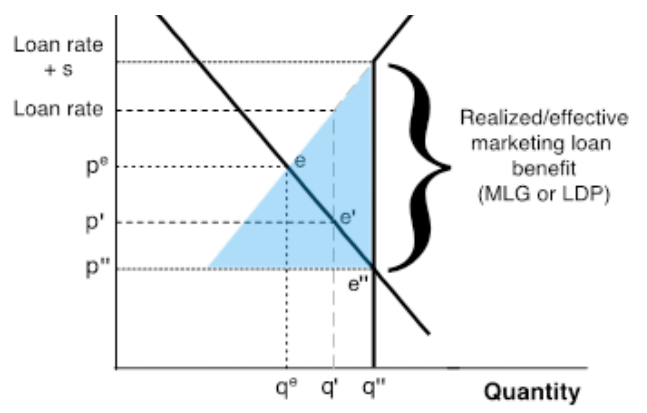

MLG = Marketing Loan Gain. LDP = Loan Deficiency Payment Source: Price and Westcott 2001. (Reprinted with permission.) *Modified by the author. 
Figure 4: Corn Planted Acreage

Mil. acres

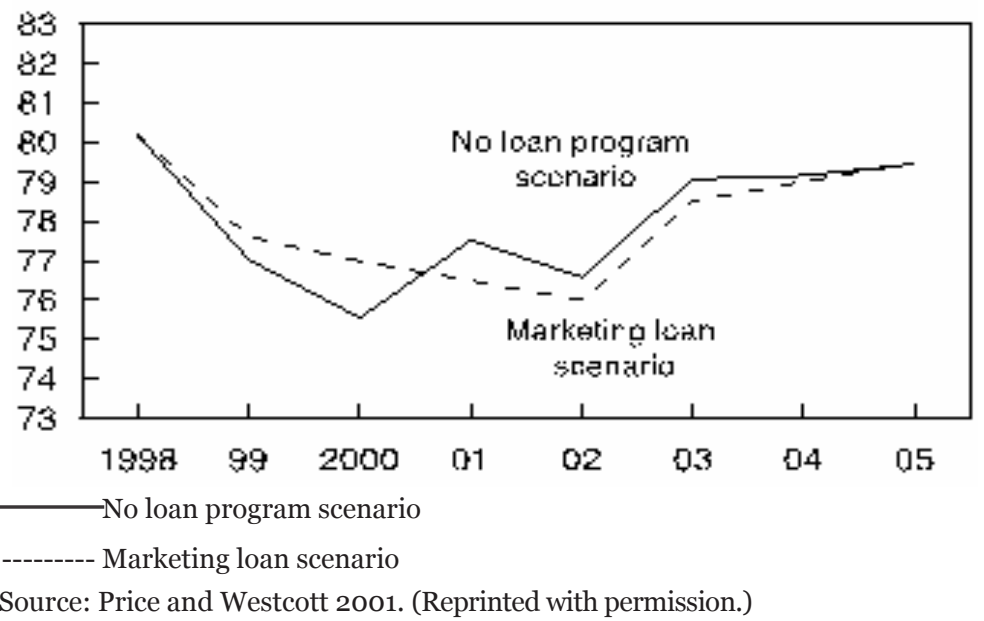

falls below the marketing assistance loan rate, would thus likely have a relatively low impact on production, market price, and corn farmer income (after loan repayment). However, an elimination of direct payments, counter-cyclical payments, and the average crop revenue election program - which are tied to historical base acreage and historical yields, and are not coupled with current production - would negatively impact the income of corn farmers who receive these subsidies.

Though these decoupled payments have little impact on current planting decisions of corn farmers, these subsidies have likely had an effect on the growth of the corn industry over time. For farmers who enter the market and assess their alternative growing options, choosing to grow commodity crops, like corn, is a more attractive option than choosing to grow other produce that does not receive subsidies. The existence of subsidies that provide income support and create a

Figure 5: Corn Prices: No Loan Program and Marketing Loan Scenarios

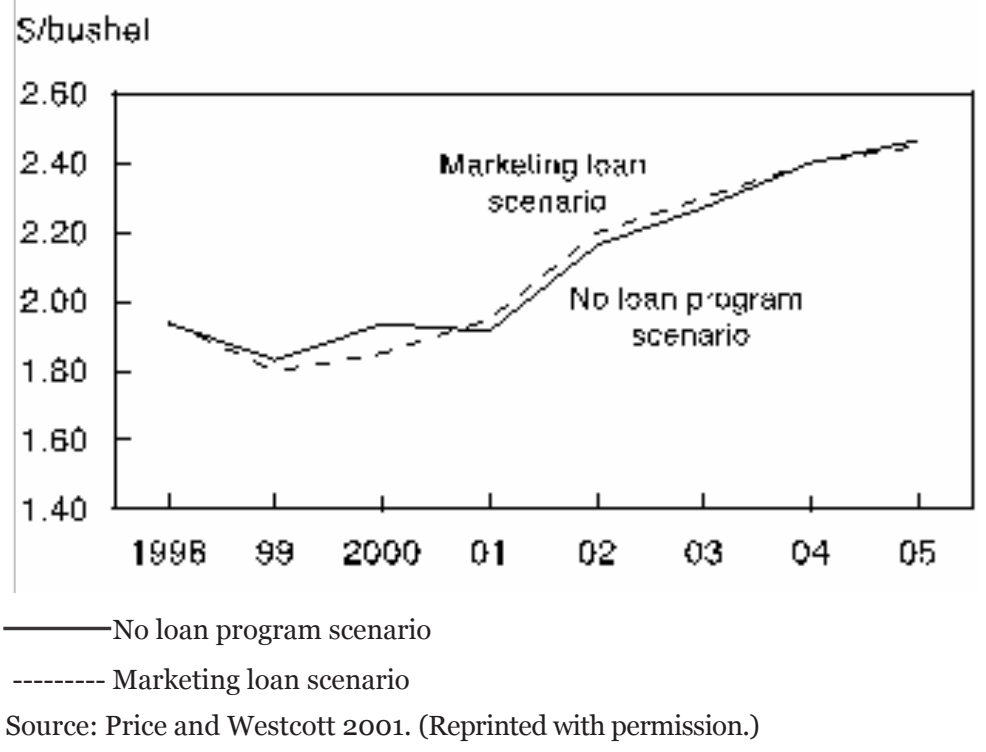


safety net for commodity crop prices in the event of a market downturn represents an incentive in itself to grow these crops over others that do not receive similar support.

If current market conditions for corn persist (with the average price of corn being continually above the marketing assistance loan rate), an assessment of the impact of decoupled payments on corn farmer income would be needed to determine the relative incentives of growing corn over other fruits and vegetables that are not covered by commodity title subsidies. Should the elimination of all commodity subsidies for corn make growing non-commodity produce more profitable, it would likely follow that many corn farmers would begin producing these al- ternative types of produce in lieu of corn. However, if it remains more profitable for farmers to grow corn rather than other types of produce even after eliminating commodity subsidies for corn, the elimination of commodity subsidies for corn would need to be accompanied by government subsidies for non-commodity crops in order to encourage farmers to produce other fruits and vegetables. Only when it becomes more profitable to grow other types of crops will we see a change in agricultural production. For this to occur, appropriate attention must be given by policymakers to the economic evaluation of farmer incentives to produce these respective crops.

\section{Appendix}

Revenue With Marketing Assistance Loan When Market Price = \$5.18/bushel

Revenue per bushel at market price $=\$ 5.18 /$ bushel

Adjusted for marketing assistance loan: $\$ 5.18+\$ 1.95=\$ 7.13$ per bushel

Revenue from marketing assistance loan and market price for corn farm of average acreage (using average yield per farm from Table 2): $\$ 7.13$ X 38,749.23 = \$276,282.01

Direct Payment (using calculation from Table 1 and values from Table 2):

$\$ 1.95$ X (.85 X 253.59 acres) X 150.8 bushels/acre x $\$ 0.28=\$ 17,747.82$

Total revenue: $\$ 276,282.01+\$ 17,747.82=\$ 294,029.83$

Revenue After Loan Repayment When Market Price = \$5.18/bushel

Total revenue (from previous calculation): \$294,029.83

Marketing assistance loan repayment amount: $\$ 11,485.27$

Revenue after loan repayment: $\$ 292,190.83-\$ 11,485.27=\$ 282,544.56$.

Revenue When Market Price $=\$ 1.50 /$ bushel

Total revenue $=\$ 238,684.84$

Value of corn stored as collateral/loan repayment amount: $\$ 58,123.85$

Revenue after collateral is forgone or loan is repaid: $\$ 238,684.84-\$ 58,123.85=$ $\$ 180,560.99$

Marketing Loan Gain Received When Market Price $=\$ 1.5 \mathrm{O} /$ bushel

Marketing loan gain $=($ marketing assistance loan per bushel - loan repayment amount per bushel) $\mathrm{X}$ total bushels

Total yield (from Table 2): 38,749.23 bushels

Marketing loan gain: $(\$ 1.95$ - \$1.50) X 38,749.23 = \$17,437.15 


\section{References}

Barrionuevo, Alexei. 2005. "Mountains of Corn and a Sea of Farm Subsidies." The New York Times, November 9. http://www.nytimes.com/2005/11/o9/ business/ogharvest.html?pagewanted=all\&_r=0.

Monke, Jim. 2006. "CRS Report for Congress: Farm Commodity Programs - Direct Payments, Counter-Cyclical Payments and Marketing Loans.” March 1.

Pollan, Michael. 2008. In Defense of Food. New York, New York: The Penguin Group.

Price, J. Michael, and Paul C. Westcott. 2001. "Analysis of the U.S. Commodity Loan Program with Marketing Loan Provisions.” April.

Roberts, Paul. 2008. The End of Food. New York, New York: Houghton Mifflin Company. 161.

USDA ERS (Economic Research Service). 2008. “2008 Farm Bill Side-By-Side: Title 1: Commodity Programs.” Last modified December 11, 2008. http://webarchives. cdlib.org/sw1tx36512/http://ers.usda.gov/FarmBill/2008/Titles/TitleIcommodities.htm.

---. 2012a. "Farm and Commodity Policy: Program Provisions." Last modified October 29, 2012. http://www.ers.usda.gov/topics/farm-economy/farm-commodity-policy/program-provisions.aspx.

- - . 2012b. "Farm and Commodity Policy: What is Meant by Decoupling?" Last modified October 29, 2012. http://www.ers.usda.gov/topics/

farm-economy/farm-commodity-policy/what-is-meant-by-decoupling.aspx.

--—. 2012c. "Farm and Commodity Policy: Glossary-Marketing Loan Repayment Rate." Last modified May 30, 2012. http://www.ers.usda.gov/ topics/farm-economy/farm-commodity-policy/glossary.aspx.

-—-. 2012d. "Farm and Commodity Policy: Program Provisions: Direct Payments." Last modified October 29, 2012. http://www.ers.usda.gov/

topics/farm-economy/farm-commodity-policy/program-provisions/ direct-payments.aspx.

- - . 2012e. "Farm and Commodity Policy: Program Provisions: Counter-Cyclical Payments." Last modified October 29, 2012. http://www.ers.

usda.gov/topics/farm-economy/farm-commodity-policy/programprovisions/counter-cyclical-payments.aspx.

- - . 2012f. "Farm and Commodity Policy: Program Provisions: Average Crop Revenue Election (ACRE).” Last modified November 2, 2012. http://www.ers. usda.gov/topics/farm-economy/farm-commodity-policy/program-provisions/ average-crop-revenue-election-(acre).aspx.

-_- 2012g. "Farm and Commodity Policy: Program Provisions: Marketing assistance loans and Loan Deficiency Payments.” Last modified November 2, 2012. http:// www.ers.usda.gov/topics/farm-economy/farm-commodity-policy/programprovisions/marketing-assistance-loans-loan-deficiency-payments.aspx.

-_-. 2013a. "Data Sets: New Feed Grains Data: Yearbook Tables. Table 1 - Corn, sorghum, barley, and oats: Planted acreage, harvested acreage, production, yield, and farm price." Last modified February 13, 2013. http://www.ers.usda.gov/ data-products/feed-grains-database/feed-grains-yearbook-tables.aspx.

- - . 2013b. "Data Sets: New Feed Grains Data: Yearbook Tables. Table 9 - Corn and sorghum: Average prices received by farmers, United States.” Last modified February 13, 2013. http://www.ers.usda.gov/data-products/feed-grains-database/feed-grains-yearbook-tables.aspx.

USDA FSA (Farm Service Agency). 2010. "News Releases: USDA Announces Commodity 
Credit Corporation Lending Rates for June 2010.” Last Modified June 1, 2010. http://www.fsa.usda.gov/FSA/newsReleases?area=newsroom\&subject=landin g\&topic $=$ ner\&newstype $=$ newsrel\&type $=$ detail\&item $=$ nr_20100601_rel_0045. html.

-—-. 2011a. "Price Support: Commodity Loans.” Last Modified June 29, 2011. http:// www.fsa.usda.gov/FSA/webapp?area=home\&subject

$=$ prsu\&topic $=$ col.

-—-. 2011b. "Newsroom: Program Fact Sheets.” Last Modified April, 2011. http:// www.fsa.usda.gov/FSA/newsReleases?area=newsroom

\&subject $=$ landing\&topic $=$ pfs\&newstype $=$ prfactsheet\&type $=$ detail\&ite $\mathrm{m}=$ pf_20110419_insup_en_maldp.html

-_-. 2012. "Newsroom: Program Fact Sheets- Direct and Counter-Cyclical Payment Program.” Last Modified January 2012. http://www.fsa.usda.gov/FSA/newsR eleases?area $=$ newsroom\&subject $=$ landing\&topic $=$ pfs\&newstype $=$ prfactsheet $\&$ type=detail\&item=pf_20120112_insup_en_dcp.html.

Dana Hecht is a second year Master of Public Policy student at The George Washington University, concentrating in food and agricultural policy. She earned a BA in human biology and graduated with high distinction from the University of Virginia in 2009. Though her academic focus was in agricultural policy while she was a student at GW, upon graduating she will be applying her master's degree experience toward advancing her program evaluation skills at the Center for Nonprofit Excellence in Charlottesville, Virginia.

The author thanks Anne Berry, Kristin Hubing, Max Bentovim and Hasan Bhatty for the endless hours they spent editing this paper, and Antonio Gayoso for his insightful guidance on the paper's focus and direction. She also thanks Professor Gerald Brock for providing the opportunity to begin writing this paper as a coursework assignment in the fall of 2011 and for providing the very first round of feedback and advice. 